Article

\title{
Comparison of Changes in Urban Land Use/Cover and Efficiency of Megaregions in China from 1980 to 2015
}

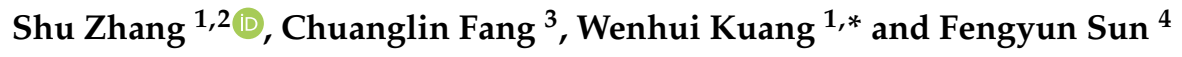 \\ 1 Key Laboratory of Land Surface Pattern and Simulation, Institute of Geographic Sciences and Natural \\ Resources Research, Chinese Academy of Sciences, Beijing 100101, China \\ 2 College of Resource and Environment, University of Chinese Academy of Sciences, Beijing 100049, China \\ 3 Key Laboratory of Regional Sustainable Development Modeling, Institute of Geographic Sciences and \\ Natural Resources Research, Chinese Academy of Sciences, Beijing 100101, China \\ 4 School of Ecological and Environmental Sciences, East China Normal University, Shanghai 200241, China \\ * Correspondence: kuangwh@igsnrr.ac.cn; Tel.: +86-135-2125-8850
}

Received: 23 June 2019; Accepted: 2 August 2019; Published: 6 August 2019

check for updates

\begin{abstract}
Urban land use/cover and efficiency are important indicators of the degree of urbanization. However, research about comparing their changes at the megaregion level is relatively rare. In this study, we depicted the differences and inequalities of urban land and efficiency among megaregions in China using China's Land Use/cover Dataset (CLUD) and China's Urban Land Use/cover Dataset (CLUD-Urban). Furthermore, we analyzed regional inequality using the Theil index. The results indicated that the Guangdong-Hong Kong-Macao Great Bay Area had the highest proportion of urban land $(8.03 \%)$, while the Chengdu-Chongqing Megaregion had the highest proportion of developed land $(64.70 \%)$. The proportion of urban impervious surface area was highest in the Guangdong-Hong Kong-Macao Great Bay Area (75.16\%) and lowest in the Chengdu-Chongqing Megaregion (67.19\%). Furthermore, the highest urban expansion occurred in the Yangtze River Delta $\left(260.52 \mathrm{~km}^{2} / \mathrm{a}\right)$, and the fastest period was 2000-2010 $\left(298.19 \mathrm{~km}^{2} / \mathrm{a}\right)$. The decreasing Theil index values for the urban population and economic density were 0.305 and 1.748 , respectively, in 1980-2015. This study depicted the development trajectory of different megaregions, and will expect to provide a valuable insight and new knowledge on reasonable urban growth modes and sustainable goals in urban planning and management.
\end{abstract}

Keywords: urban land use/cover; urban land efficiency; CLUD; CLUD-Urban; Theil index; megaregions

\section{Introduction}

Numerous studies characterize urban land changes and their ecological effects in different regions. With urban land change, a series of urban problems have emerged, including climate change [1-5], urban heat islands [6,7], air pollution [8,9], deterioration of the water environment [10], degradation of the ecological environment [11-14], soil taking problems [15], and sprinkling and loss of land for agri-food [16-18]. Urbanization has been witnessed all around the world, growing from $29.61 \%$ in 1950 to $55.29 \%$ in 2018 [19]. More than 3.4 billion people flew into cities since 1950, with $84.22 \%$ of them belonging to less developed regions. As one of the fastest urbanizing regions in the world, an unprecedented urbanization trend was established in East-Southeastern Asia [20,21]. Among them, China witnessed one of the fastest urbanization phenomena [22]. China started the policy of "reform and opening-up" in 1978, the speed and scale of China's urbanization over the past four decades represents a staggering feat in world history [23,24]. The urban population of China reached 863 million in 2018 , which was equivalent to $20.5 \%$ of the world [19]. 
Urban land and its efficiency are indicators used to portray developed degree of cities. Numerous studies have been conducted on urban land characterization, such as urban area [25], urban expansion [26,27], urban land landscape patterns [28-30], urban land density [31], urban internal structure [32-34] and urban land efficiency [35-37]. Among them, urban land can reflect the characteristics of landscape patterns, such as urban area and compactness [26]; urban internal structures, such as the percentage of impervious surface area, can reflect the characteristic of the degree of internal artificial construction intensity [32,38,39]. The urban population and economy are important parameters for portraying urban development [40]. The population and economic production relative to the unit area of the city can reflect the differences in urban land use efficiency. These studies generally depict urban megaregions using indexes in only one respect. Few studies have conducted comprehensive research on making consistent large-scale comparisons.

A megaregion is an emerging concept used for characterizing urban organic communities [41]. It is an urban organization defined as a network of metropolitan areas and their surrounding areas. Compared with the concepts of individual cities and urban agglomerations, megaregions have larger areas and can better reflect the characteristics of urban areas [42,43]. Due to geographical complexity, regional divergence is witnessed for different megaregions, it is important to characterize the developmental trajectory of different urban megaregions [44]. Recently, some scholars put their interest on characterizing the urbanization process at megaregion level, such as urban sprawl phenomenon [37], spatial pattern of urban change [45,46], and uneven growth [47]. However, previous studies were conducted more to characterize urbanization process. Research devoted to characterize spatial-temporal inequalities of urban land and it associated efficiency is relatively rare among megaregions.

This study performed a comparative analysis of changes in urban land use/cover and efficiency in megaregions in China from 1980 to 2015. Here, we focus on five major megaregions of China: Beijing-Tianjin-Hebei Megaregion, Yangtze River Delta Megaregion, Guangdong-Hong Kong-Macao Great Bay Area, Middle Yangtze River Megaregion and Chengdu-Chongqing Megaregion. The urban land use/cover changes and efficiency are depicted by a list of indexes, which were derived from the China's Land Use/cover Dataset (CLUD) and China's Urban Land Use/cover Dataset (CLUD-Urban). datasets and social-economic factors at the national level. To quantify the changes in urban land and efficiency, the percentage of urban land and developed land, the urban expansion area, the percentage of impervious surface area within cities, the urban population density (population per urban area), and the urban economic density (GDP per urban area) were used. To further characterize the regional divergence of urban land efficiency, the Theil index was employed. This study depicted the differences and inequalities among different megaregions of China, which may help implement the National New-Type Urbanization Plan in China $[48,49]$ and is critical to achieving sustainable urban development [50,51].

\section{Study Area}

Megaregions have experienced and witnessed dramatic changes in China and continue to play leading roles in China's future economic development. As national-level megaregions are major urban areas in China, they are home to most of the population and GDP. Five major megaregions were selected at the national level for analysis (Table 1, Figure 1), including the Beijing (Jing)-Tianjin (Jin)-Hebei (Ji) Megaregion (JJJ), Yangtze River Delta Megaregion (YRD), Guangdong (Yue)-Hong Kong (Gang)-Macao (Ao) Great Bay Area (YGA), Middle Yangtze River Megaregion (MYR) and Chengdu (Cheng)-Chongqing (Yu) Megaregion (CY). 
Table 1. Information of megaregions.

\begin{tabular}{cccc}
\hline Name & Short Name & Population (million) & Area $\mathbf{( 1 0}^{\mathbf{4}} \mathbf{k m}^{\mathbf{2}} \mathbf{~}$ \\
\hline Beijing-Tianjin-Hebei Megaregion & JJJ & 100.26 & 21.63 \\
\hline Yangtze River Delta Megaregion & YRD & 134.79 & 21.56 \\
\hline Guangdong-Hong Kong-Macao Great Bay Area & YGA & 34.64 & 5.72 \\
\hline Middle Yangtze River Megaregion & MYR & 135.84 & 34.26 \\
\hline Chengdu-Chongqing Megaregion & CY & 109.94 & 23.95 \\
\hline
\end{tabular}

Note: The population was extracted from the data of 2017.

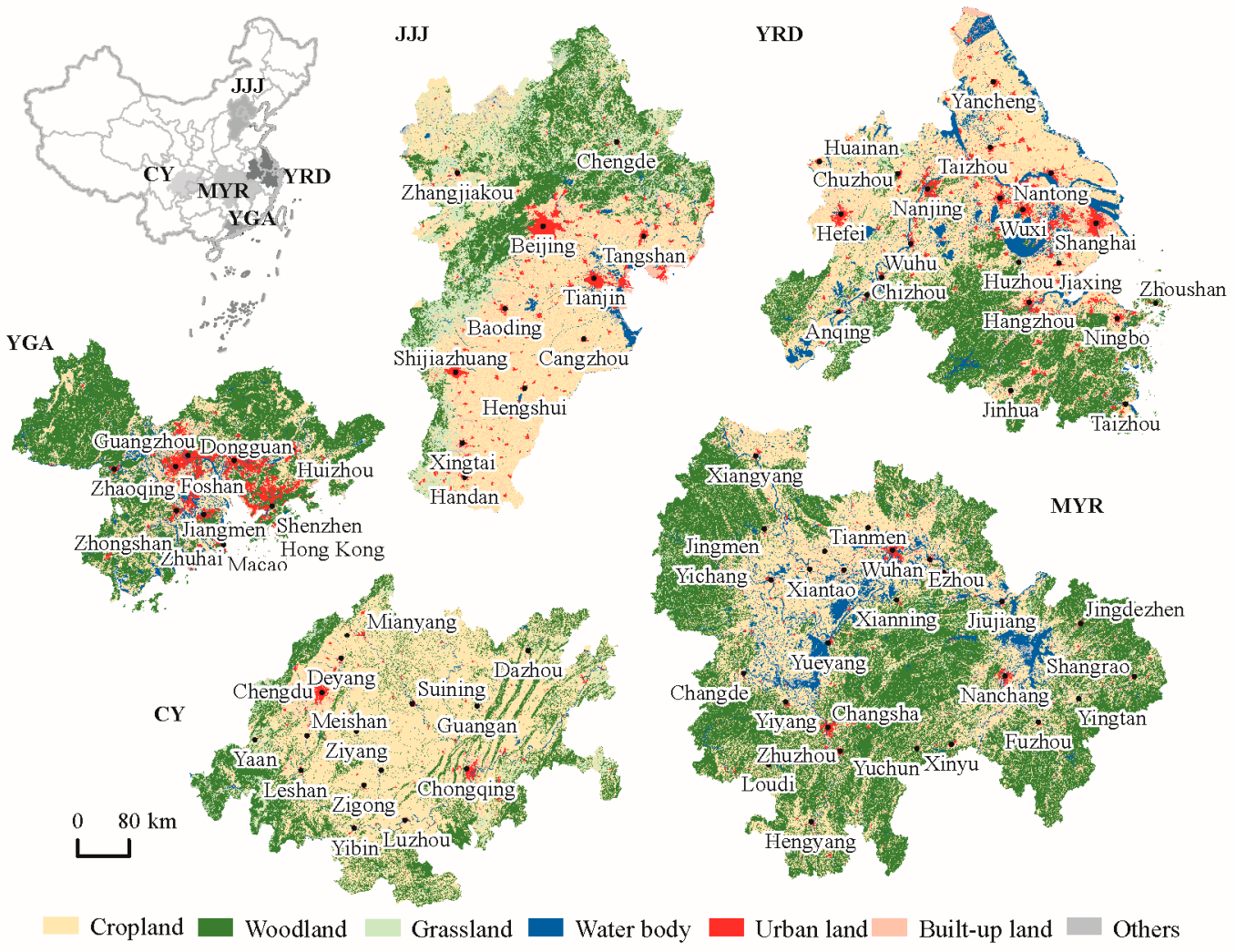

Figure 1. Study area and the location of the megaregions.

Sitting on the northeastern coast of China, JJJ is home to 100.26 million people and covers an area of $21.63 \times 10^{4} \mathrm{~km}^{2} . \mathrm{JJ}$ is the central site of the politics and culture of China, and the region includes Beijing and Tianjin. The emerging new area, Xiong'an, is also located in this megaregion. YRD is home to 134.79 million people and covers an area of $21.56 \times 10^{4} \mathrm{~km}^{2}$ on the plain before the Yangtze River enters the sea. It includes the largest Chinese city, Shanghai, and a list of cities, such as Hangzhou, Nanjing, Suzhou, and Hefei. YGA is home to 34.64 million people and covers an area of $5.72 \times 10^{4} \mathrm{~km}^{2}$ at the delta before the Pearl River enters the sea. YGA has been one of the most durable economic centers since the 1980s, including the main megacities of China: Guangzhou, Shenzhen, Dongguan, etc. Two special administrative regions, Hong Kong and Macao, are located in this megaregion. MYR encompasses approximately $34.26 \times 10^{4} \mathrm{~km}^{2}$ in the middle of China and is home to 135.84 million people. It is an emerging megaregion compared to JJJ, YRD and YGA. It includes Wuhan, a rapidly developing megacity, and Changsha and Nanchang, two main metropolises. CY encompasses approximately $10.68 \times 10^{4} \mathrm{~km}^{2}$ upstream of the Yangtze River and is home to 109.94 million people. It is named for its two megacities: Chengdu and Chongqing. 
The boundaries of the megaregions were defined by the master plan from the State Council [52]. In our study, a prefecture-level city, which provides detailed social-economic information, was chosen for analysis. The auxiliary data were extracted from the National Catalogue Service For Geographic Information supposed by National Geomatics Center of China (http://www.webmap.cn/main.do? method=index).

\section{Data and Methods}

The analysis process is shown in Figure 2. Quantitative indexes were designed to depict the degree of artificial construction density and urban land efficiency. We used CLUD and CLUD-Urban datasets for urban land extraction. The urban area and urban ISA from these datasets were acquired to analyze the degree of the artificial construction density, including the urban land percentage and ISA percentage. The urban expansion area in each period was derived from CLUD. Population and economic data, with urban land area, were obtained to depict urban land efficiency. Then, we compared the temporal changes in indexes among megaregions. The Theil index was used to determine inequality characteristics among and within megaregions.

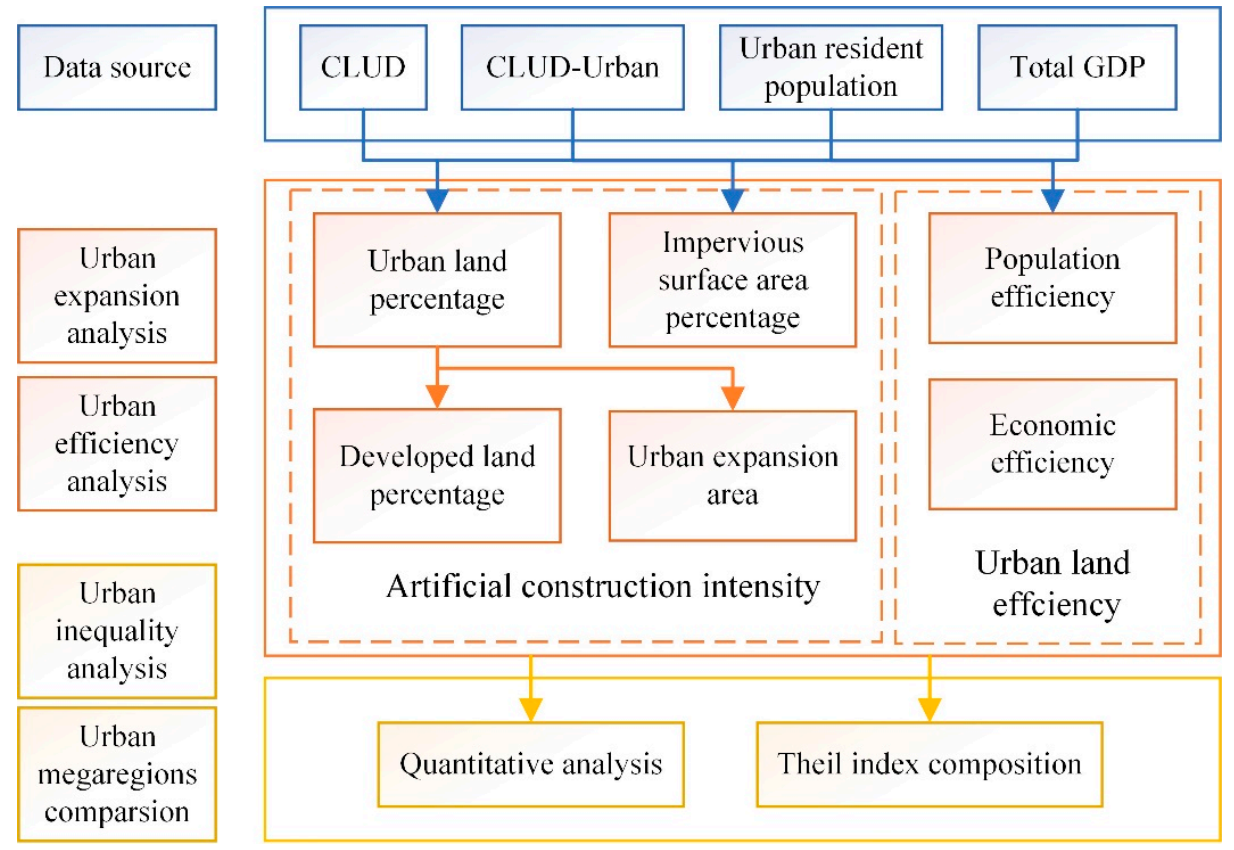

Figure 2. Flow chart on analysis of artificial construction intensity and urban land efficiency.

\subsection{Dataset of Urban Land Use/Cover Change}

The CLUD and CLUD-Urban datasets were employed in this study. The CLUDs have been adopted to explore various topics, including cropland change and urban expansion [25]. Validation of the CLUDs was performed in other research, which have an overall accuracy over 90\% [53,54]. We integrated the land use/cover classification system of CLUD. All first level types, including cropland, woodland, grassland, water bodies, built-up land and others, together with urban land type were adopted (Table 2). The land use/cover classification was integrated into two parts according to the leading function of land use. The land whose leading function is living and production is defined as the highly developed land, including cropland and built-up land. The land whose leading function is ecology is defined as the low developed land, including woodland, grassland, water bodies and others [55]. The degree of artificial construction intensity is measured by the proportion of highly developed land and urban land. A high proportion indicates a high degree of artificial construction intensity. 
Table 2. The land use/cover classification system.

\begin{tabular}{ll}
\hline Land Use/Cover Types & \multicolumn{1}{c}{ Description } \\
\hline Cropland & $\begin{array}{l}\text { Crop-based land, including beaches and tidal flats that have been cultivated for } \\
\text { more than three years. }\end{array}$ \\
\hline Woodland & Forestry land such as growing trees, shrubs, bamboos, and coastal mangroves. \\
\hline Grassland & $\begin{array}{l}\text { Grass-covered land with growing herbaceous plants whose coverage higher } \\
\text { than 5\%. }\end{array}$ \\
\hline Water bodies & Natural land waters and land for water conservancy facilities. \\
\hline Urban land & Land for urban built-up areas. \\
\hline Other built-up land & $\begin{array}{l}\text { Land for rural settlements, industrial and mining, and transportation beyond } \\
\text { the city }\end{array}$ \\
\hline Others & Other land use/cover types, such as sandy land, bare soil and swampland. \\
\hline
\end{tabular}

Urban land use/cover change datasets from CLUD-Urban were employed for inter-structure analysis. In previous study, urban structure was composed of different land use/cover types, such as impervious surfaces, vegetation and soil [56]. As a mixed pixel phenomenon occurs, the dataset is characterized the pattern of urban structure by the fraction of a land use/cover type in a pixel [33]. The urban ISA fraction from CLUD-Urban was selected for the urban internal artificial construction intensity measurement. The accuracy of the urban ISA was examined by R-squares, which reached $0.82[57]$.

\subsection{Acquirement of Social-Economic Factors}

The urban resident population was chosen as the population data. To solve the problem of missing data, we used the total population data and urbanization rate to estimate the urban resident population. Economic data were measured by total GDP. The statistical factors at the prefecture level were used for analysis. The factors were derived from the China Statistical Yearbook and the China City Statistical Yearbook for 1981, 1991, 2001, 2011 and 2016 [58,59]. Some city-level statistical data from China Economic and Social Big Data Research Platform (http://data.cnki.net/) were also employed for supplementation.

\subsection{Quantification of Urban Land and Its Efficiency Change}

To quantify the urban land and its efficiency change, the indexes were chosen as an index system for characteristics. The index system is depicted by five indexes, including artificial construction intensity, urban expansion, urban internal structure, urban population and urban economics of megaregions.

The artificial construction intensity is characterized by the percentage of urban land and highly developed land in a megaregion. The urban land change is depicted by the urban land expansion and urban internal structure. Urban land expansion is the area of urban expansion of a megaregion per year. The urban internal structure is characterized by the fraction of impervious surface area. These variables are calculated by the following formulas:

$$
\begin{gathered}
\text { Urban area percentage }(\mathrm{UAP})=\mathrm{UA} / \mathrm{MA}, \\
\text { Highly developed land percentage }(\mathrm{DAP})=\mathrm{HDA} / \mathrm{MA}, \\
\text { Urban expansion area }(\mathrm{UEA})=\mathrm{UA}_{\mathrm{i}+1}-\mathrm{UA}_{\mathrm{i}}, \\
\text { Impervious surface area percentage }(\mathrm{ISP})=\mathrm{ISA} / \mathrm{UA}
\end{gathered}
$$

where UA is the area of urban land in a megaregion, MA is the area of the megaregion, HDA is the area of the highly developed land in the megaregion, $\mathrm{UA}_{\mathrm{i}+1}$ is the area of urban land in the posterior 
year, $\mathrm{UA}_{\mathrm{i}}$ is the area of urban land in the prior year, and ISA is the area of impervious surface within urban land in a megaregion.

The urban land efficiency is characterized by the density of the urban population and economy. We defined the density as the value per unit of urban land. A higher density indicates there is more value generated on a unit of urban land; thus, the unit of urban land is more efficient. The urban resident population and total GDP were chosen to characterize the urban population and economic situation. The density is calculated by the following formulas:

$$
\begin{aligned}
& \text { Urban population density }=\mathrm{URP} / \mathrm{UA}, \\
& \text { Urban economic density }=\text { TGDP/UA }
\end{aligned}
$$

where URP is the population of urban resident, TGDP is the total GDP in urban administrative unit, UA is the area of urban land in a megaregion as well.

\subsection{Characterization of Regional Divergence of Urban Land Efficiency}

The Theil index was used to measure the inequality among variations, such as that of economic development [60]. The Theil index can be used to analyze inequalities among and within areas. We used the Theil index for regional inequality analysis, which can be decomposed into the following two parts:

$$
\mathrm{T}_{\text {total }}=\mathrm{T}_{\mathrm{a}}+\mathrm{T}_{\mathrm{w}}
$$

where $T_{a}$ refers to the Theil index values among megaregions, $T_{w}$ refers to the Theil index values within megaregions, and $\mathrm{T}_{\text {total }}$ refers to the overall difference.

$$
\begin{gathered}
\mathrm{T}_{\mathrm{a}}=\sum_{\mathrm{i}=1}^{\mathrm{n}} \mathrm{y}_{\mathrm{i}} \log \frac{\mathrm{y}_{\mathrm{i}}}{\mathrm{p}_{\mathrm{i}}} \\
\mathrm{T}_{\mathrm{w}}=\sum_{\mathrm{i}=1}^{\mathrm{n}} \mathrm{y}_{\mathrm{i}}\left(\sum_{\mathrm{j}=1}^{\mathrm{i}} \mathrm{y}_{\mathrm{ij}} \log \frac{\mathrm{y}_{\mathrm{ij}}}{\mathrm{p}_{\mathrm{ij}}}\right)
\end{gathered}
$$

where $\mathrm{n}$ refers to the number of groups, $\mathrm{y}_{\mathrm{i}}$ refers to the index in the ratio in group $\mathrm{i}$ to the entire index in the region, $p_{i}$ refers the number in group $i$ to the entire index in the region, $y_{i j}$ refers to the index in the ratio in group $i$ to the entire index in city $j$, and $p_{i j}$ refers to the number in group $i$ to the entire index in city $\mathrm{j}$. A higher Theil index value indicates more inequality in a region.

The Theil index was also used to analyze the inequality of different megaregions:

$$
\mathrm{T}_{\mathrm{m}}=\sum_{\mathrm{i}=1}^{\mathrm{n}} \mathrm{y}_{\mathrm{i}} \log \frac{\mathrm{y}_{\mathrm{i}}}{\mathrm{p}_{\mathrm{i}}}
$$

where $T_{m}$ refers to the Theil index of a megaregion, $n$ refers to the number of groups, $y_{i}$ refers to the index in the ratio in group $i$ to the entire index in the megaregion, and $p_{i}$ refers to the number in group $i$ to the entire index in the megaregion.

\section{Results}

\subsection{Different Degrees of Artificial Construction Intensity}

The degrees of artificial construction intensity are shown as the UAP, DAP and ISP (Figures 3 and 4). We analyzed the proportion of land use/cover type among megaregions in 2015 (Table 1). Regarding UAP and DAP, CY had the highest proportion of developed land among the five megaregions. However, it had the highest proportion of cropland and the lowest proportion of urban land. The degree of artificial construction intensity was reflected by agriculture. Because more hills are distributed in YGA and MYR, 
there is more green space, including woodland and grassland, in the two megaregions. This pattern indicated a relatively low artificial construction intensity. Although YGA had the highest proportion of urban land, reaching $8.03 \%$ in 2015, the ecological environment was still good. The proportion of low developed land was the highest among the five megaregions, reaching $63.08 \%$ in 2015 . JJJ and YRD had relatively high proportions of highly developed land, reaching $60.57 \%$ and $59.71 \%$, respectively. The two megaregions had a relatively high proportion of built-up land, showing a high degree of artificial construction intensity.

Compared with the UAP or DAP, the ISP has remained steady since the 21st century for the five megaregions (Table 3). However, a slight increase was shown in the mean ISP, increasing from $68.84 \%$ in 2000 to $70.23 \%$ in 2010 to $71.03 \%$ in 2015 . The regional divergence was shown by the ISP, reflecting a pattern in the urban structure. According to the ISP in 2015, YGA experienced the highest ISP (75.16\%). This result may be caused by relatively intensive urban construction. CY experienced the lowest ISP (67.09\%). This result may be because more natural green remains inside the cities instead of ISA growth. Chongqing had an ISP of 56.54\% in 2015 (Figure 4), which means that only half of the urban land was covered by an impervious surface. All megaregions had a slight increase in the proportion of ISA from 2000 to 2015 . The range of increase was less than $5 \%$.
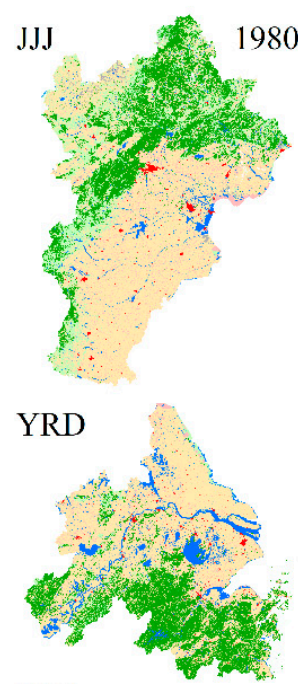

YGA
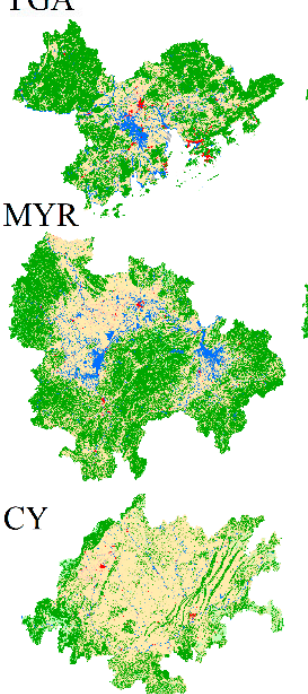

Cropland
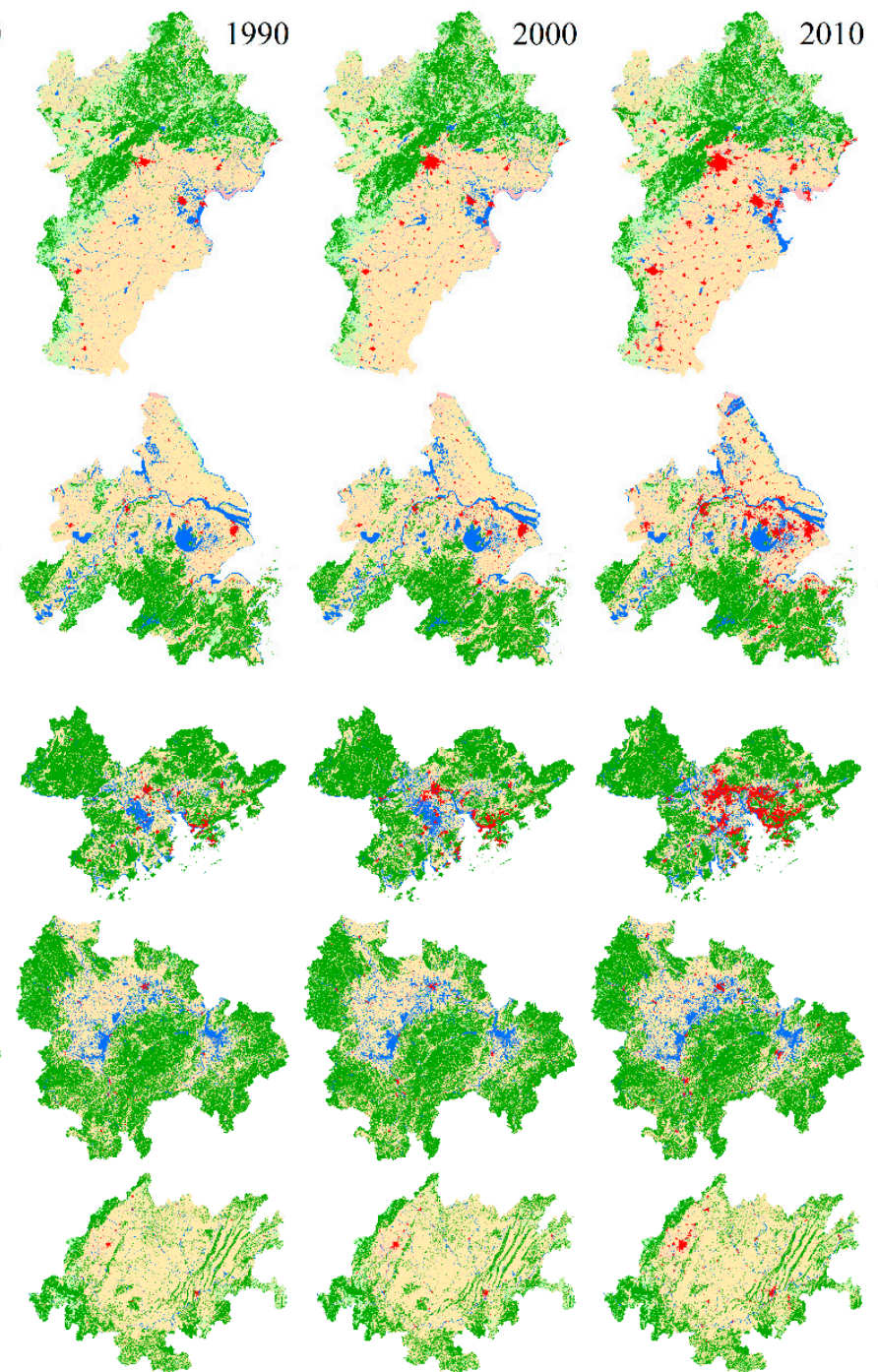

Urban land

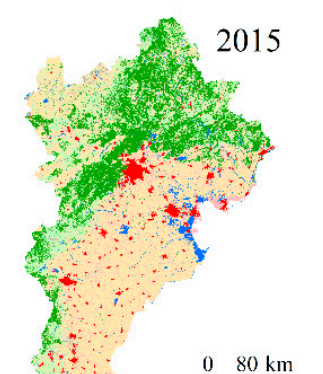

\llcorner
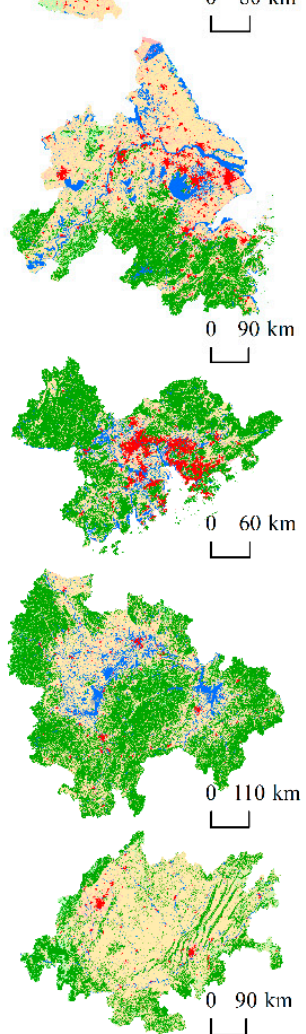

Others

Figure 3. Urban expansion in the five megaregions. 


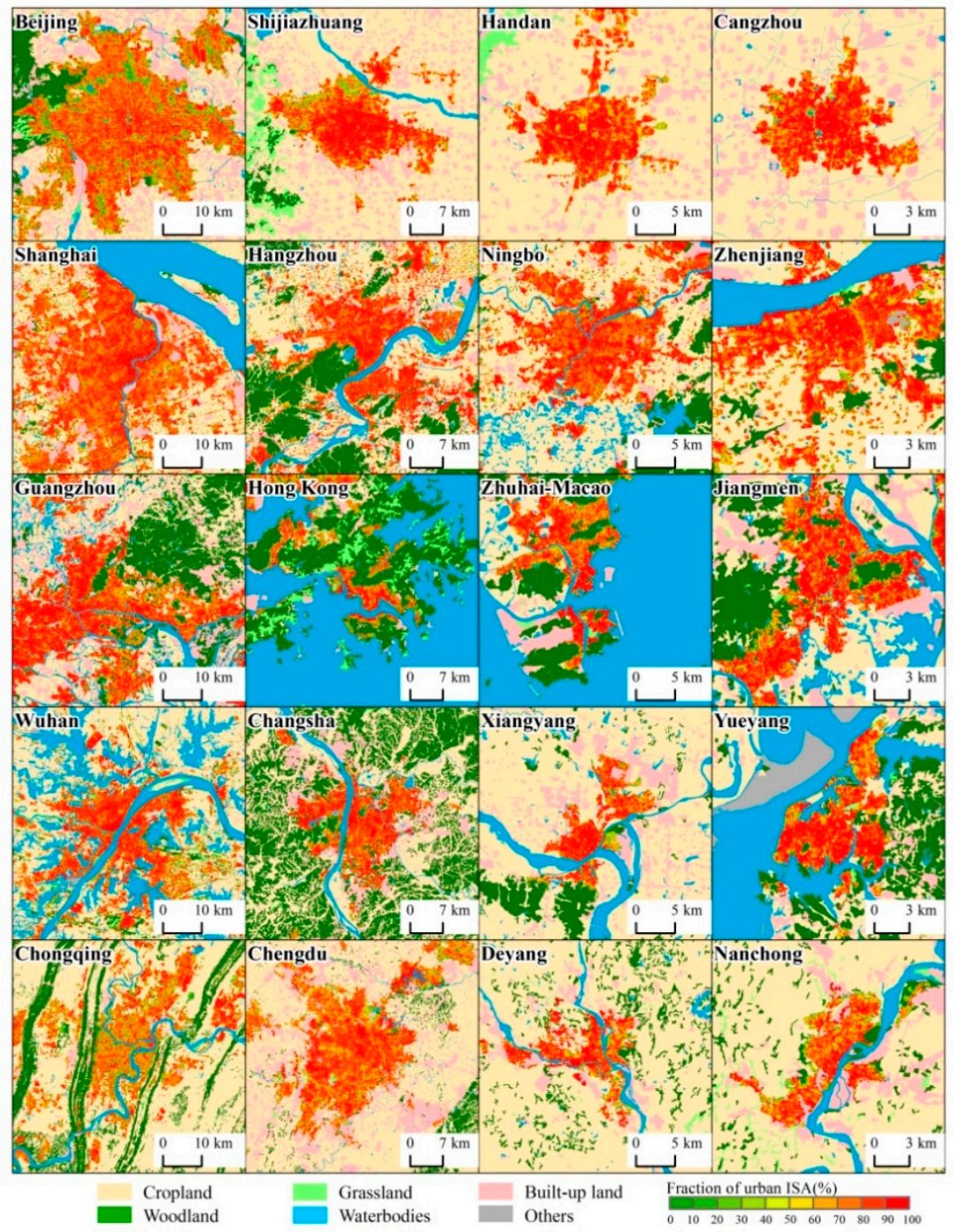

Figure 4. The urban impervious density from CLUD-Urban for cities in 2015.

Table 3. Proportion of land use/cover type among megaregions in 2015.

\begin{tabular}{cccccc}
\hline Land Use/Cover Type & JJJ & YRD & YGA & MYR & CY \\
\hline Highly developed land & $60.57 \%$ & $59.71 \%$ & $36.92 \%$ & $41.78 \%$ & $64.70 \%$ \\
Cropland & $47.70 \%$ & $46.29 \%$ & $22.72 \%$ & $36.90 \%$ & $61.39 \%$ \\
Urban land & $3.73 \%$ & $5.24 \%$ & $8.03 \%$ & $1.54 \%$ & $1.04 \%$ \\
Other built-up land & $9.15 \%$ & $8.17 \%$ & $6.17 \%$ & $3.34 \%$ & $2.26 \%$ \\
Low developed land & $39.43 \%$ & $40.29 \%$ & $63.08 \%$ & $58.22 \%$ & $35.30 \%$ \\
Woodland & $20.72 \%$ & $26.74 \%$ & $53.74 \%$ & $48.38 \%$ & $27.44 \%$ \\
Grassland & $15.41 \%$ & $3.35 \%$ & $2.25 \%$ & $2.26 \%$ & $5.85 \%$ \\
Water body & $2.73 \%$ & $10.04 \%$ & $6.86 \%$ & $7.26 \%$ & $1.65 \%$ \\
Others & $0.57 \%$ & $0.16 \%$ & $0.24 \%$ & $0.32 \%$ & $0.36 \%$ \\
Impervious surface area & $70.95 \%$ & $71.81 \%$ & $75.16 \%$ & $70.16 \%$ & $67.09 \%$ \\
\hline
\end{tabular}

\subsection{Comparison of Urban Expansion Among Chinese Megaregions}

Urban land change is characterized by the following two parts: UAP and ISP. Based on the CLUD-Urban datasets, urban land expansion has occurred in all five Chinese megaregions (Figure 5). There was a pattern of greater expansion among megaregions on the eastern coast (YRD, JJJ, YGA), followed by emerging urban megaregions (MYR, CY). For the period of 1980-2015, the fastest 
expansion was observed in YRD, with $260.52 \mathrm{~km}^{2} / \mathrm{a}$ of UEA. This was followed by JJJ, MYR, and YGA. CY experienced the slowest expansion, with $52.73 \mathrm{~km}^{2} / \mathrm{a}$ of UEA and only $20.24 \%$ of YRD.

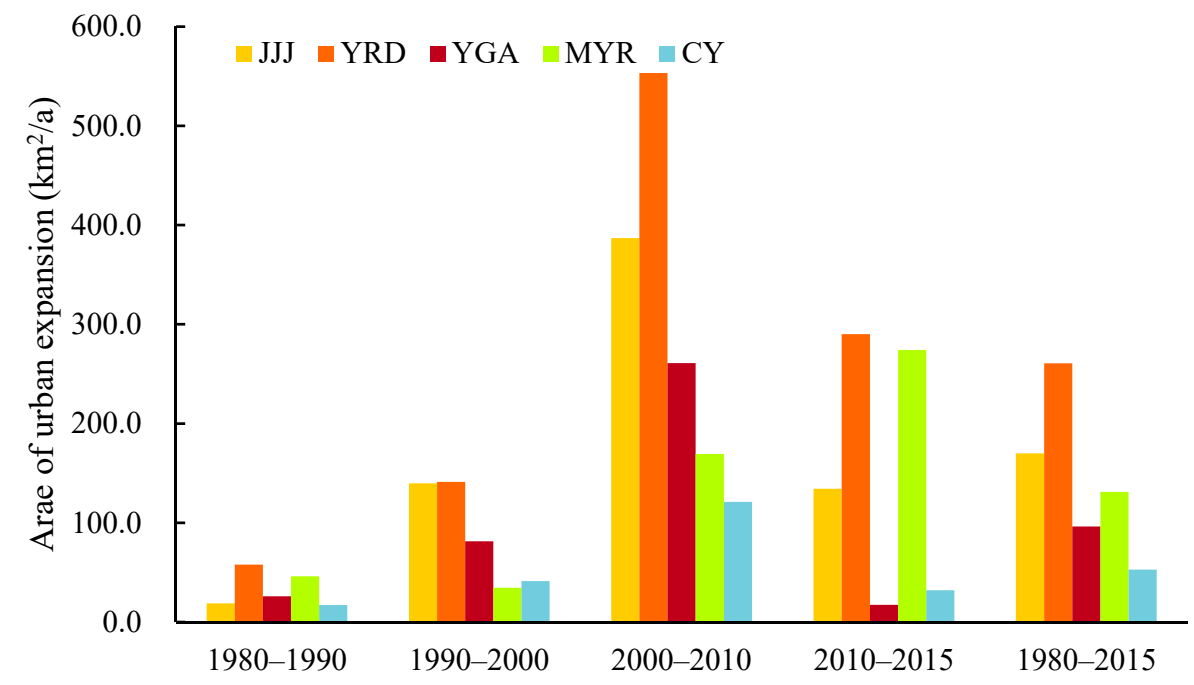

Figure 5. Regional divergence of the urban land expansion.

The overall dynamic showed an accelerating trend before 2010 and then slowed. For each period of urban expansion, the fastest expansion occurred during 2000-2010 for most megaregions except for MYR. The mean UEA was $298.19 \mathrm{~km}^{2} / \mathrm{a}$. The fastest expansion occurred in this period, and the UEA of YRD was $553.26 \mathrm{~km}^{2} / \mathrm{a}$. In contrast, the slowest expansion occurred during 1980-1990 in all megaregions. The mean UEA was $33.01 \mathrm{~km}^{2} / \mathrm{a}$. For each period, CY had the lowest expansion speed $\left(16.98 \mathrm{~km}^{2} / \mathrm{a}.\right)$ in $1980-1990$. is the next slowest was YGA in $2010-2015\left(17.22 \mathrm{~km}^{2} / \mathrm{a}\right.$.).

\subsection{Comparison of Urban Land Efficiency Among Megaregions}

We compared the urban land efficiency and their change among megaregions (Table 4). In order to indicate the overall characteristics for the development of China's megaregions, the extreme values for each megaregion and mean value are shown as bold in the urban population density and urban economic density sections of Table 4 . For the urban population density, YGA had a relatively high urban population density in most periods, except in 1980. MYR had a relatively low urban population density, except in 2010. For the year 2015, the urban population density ranked from the highest to lowest was as follows: YGA, CY, YRD, MYR and JJJ. There was regional divergence in the GDP per urban area in 2015. The highest GDP per urban area occurred in YGA in 2015, with $18.68 \times 10^{12} \mathrm{Yuan} / \mathrm{km}^{2}$, which was 2.4 times higher than the lowest value in MYR in the same period, with $7.78 \times 10^{12} \mathrm{Yuan} / \mathrm{km}^{2}$. For the year 2015, the urban economic density ranked from highest to lowest was as follows: YGA, YRD, CY, JJJ and MYR.

The urban population density showed an increasing trend in all megaregions from 1980 to 2015. The highest increase appeared in YGA, increasing from $0.65 \times 10^{4} / \mathrm{km}^{2}$ to $1.25 \times 10^{4} / \mathrm{km}^{2}$. The lowest increase appeared in JJJ. The total increase was $0.11 \times 10^{4} / \mathrm{km}^{2}$. In addition, there were different increasing phenomena among periods. The highest increase appeared in YGA from 1980 to 1990, followed by that in CY from 2010 to 2015. The greatest decrease appeared in YGA from 1990 to 2000, followed by that in CY from 2000 to 2010. There was an overall slight increasing trend in the change in urban population density, which was reflected by a positive change in the mean urban population density, except during 1990-2000. 
Table 4. Urban efficiency density of different megaregions.

\begin{tabular}{|c|c|c|c|c|c|c|}
\hline \multirow{2}{*}{ Year } & $\mathrm{JJJ}$ & YRD & YGA & MYR & CY & Mean \\
\hline & \multicolumn{6}{|c|}{ Urban Population Density $\left(10^{4} / \mathrm{km}^{2}\right)$} \\
\hline 1980 & 0.74 & 0.79 & 0.65 & 0.59 & 0.90 & 0.74 \\
\hline 1990 & 0.82 & 1.01 & 1.29 & 0.58 & 1.04 & 0.95 \\
\hline 2000 & 0.74 & 0.95 & 0.98 & 0.72 & 0.98 & 0.87 \\
\hline 2010 & 0.83 & 0.97 & 1.18 & 1.00 & 0.73 & 0.94 \\
\hline \multirow[t]{2}{*}{2015} & 0.85 & 0.9 & 1.25 & 0.84 & 1.12 & 0.99 \\
\hline & \multicolumn{6}{|c|}{ Change in Urban Population Density $\left(10^{4} / \mathrm{km}^{2}\right)$} \\
\hline 1980-1990 & 0.08 & 0.22 & 0.63 & -0.01 & 0.15 & 0.21 \\
\hline 1990-2000 & -0.08 & -0.06 & -0.3 & 0.13 & -0.07 & -0.08 \\
\hline 2000-2010 & 0.09 & 0.02 & 0.2 & 0.28 & -0.24 & 0.07 \\
\hline 2010-2015 & 0.02 & -0.07 & 0.07 & -0.15 & 0.38 & 0.05 \\
\hline \multirow[t]{2}{*}{ 1980-2015 } & 0.11 & 0.11 & 0.59 & 0.25 & 0.22 & 0.26 \\
\hline & \multicolumn{6}{|c|}{ Urban Economic Density $\left(10^{8}\right.$ Yuan $\left./ \mathrm{km}^{2}\right)$} \\
\hline 1980 & 0.23 & 0.34 & 0.16 & 0.18 & 0.28 & 0.24 \\
\hline 1990 & 0.79 & 1.01 & 5.92 & 0.50 & 0.81 & 1.81 \\
\hline 2000 & 2.82 & 4.36 & 10.66 & 2.19 & 2.59 & 4.52 \\
\hline 2010 & 5.96 & 8.54 & 12.18 & 5.57 & 5.46 & 7.54 \\
\hline \multirow[t]{2}{*}{2015} & 8.71 & 12.06 & 18.68 & 7.78 & 9.68 & 11.38 \\
\hline & \multicolumn{6}{|c|}{ Change in Urban Economic Density $\left(10^{8}\right.$ Yuan $\left./ \mathrm{km}^{2}\right)$} \\
\hline 1980-1990 & 0.56 & 0.67 & 5.76 & 0.33 & 0.53 & 1.57 \\
\hline 1990-2000 & 2.03 & 3.35 & 4.75 & 1.69 & 1.78 & 2.72 \\
\hline 2000-2010 & 3.14 & 4.17 & 1.52 & 3.37 & 2.87 & 3.02 \\
\hline 2010-2015 & 2.75 & 3.52 & 6.50 & 2.22 & 4.22 & 3.84 \\
\hline 1980-2015 & 8.48 & 11.72 & 18.52 & 7.61 & 9.40 & 11.15 \\
\hline
\end{tabular}

Note: The extreme values for each megaregion and mean value are shown in bold in urban population density and urban economic density.

Unlike the urban population density, the urban economic density had a homogenized trend in all megaregions; specifically, all megaregions showed an increasing trend from 1980 to 2015. The highest increase appeared in YGA, increasing from $0.16 \times 10^{8} \mathrm{Yuan} / \mathrm{km}^{2}$ to $18.68 \times 10^{8} \mathrm{Yuan} / \mathrm{km}^{2}$. The lowest increase appeared in MYR. The range of increase was $7.61 \times 10^{8} \mathrm{Yuan} / \mathrm{km}^{2}$. A further analysis of the changes in each period was carried out. The highest increase appeared in YGA in 2010-2015, followed by that in CY in 2010-2015. The lowest increase appeared in MYR in 1980-1990, followed by that in CY in 1980-1990. A positive change in the mean urban economic density was found in all periods. Furthermore, the mean change in the urban economic density accelerated from $1.70 \times 10^{8} \mathrm{Yuan} / \mathrm{km}^{2}$ in $1980-1990$ to $4.79 \times 10^{8}$ Yuan $/ \mathrm{km}^{2}$ in 2010-2015. This pattern showed an accelerating increasing trend in the change in urban economic density.

\subsection{Quantifying the Inequality of Urban Land and Efficiency}

The Theil index was used to analyze the inequality among and within megaregions (Table 5). In Table $5, T_{a}$ refers to the Theil index among megaregions, $T_{w}$ refers to the Theil index within megaregions, and $\mathrm{T}_{\text {total }}$ refers to the overall difference. We analyzed the Theil index and its relative change in each index. 
Table 5. Theil index change in urban land.

\begin{tabular}{cccccccccc}
\hline \multirow{2}{*}{ Year } & \multicolumn{3}{c}{ Percentage of Urban Area } & \multicolumn{3}{c}{ Urban Population Density } & \multicolumn{3}{c}{ Urban Economic Density } \\
\cline { 2 - 10 } & $\mathbf{T}_{\mathbf{a}}$ & $\mathbf{T}_{\mathbf{w}}$ & $\mathbf{T}_{\text {total }}$ & $\mathbf{T}_{\mathbf{a}}$ & $\mathbf{T}_{\mathbf{w}}$ & $\mathbf{T}_{\text {total }}$ & $\mathbf{T}_{\mathbf{a}}$ & $\mathbf{T}_{\mathbf{w}}$ & $\mathbf{T}_{\text {total }}$ \\
\hline 1980 & 0.459 & 0.494 & 0.953 & 0.074 & 0.594 & 0.668 & 1.006 & 1.134 & 2.140 \\
1990 & 0.422 & 0.453 & 0.875 & 0.041 & 0.560 & 0.602 & 0.447 & 0.576 & 1.023 \\
2000 & 0.491 & 0.441 & 0.931 & 0.038 & 0.399 & 0.437 & 0.156 & 0.259 & 0.415 \\
2010 & 0.452 & 0.355 & 0.807 & 0.059 & 0.299 & 0.359 & 0.118 & 0.245 & 0.363 \\
2015 & 0.389 & 0.327 & 0.717 & 0.038 & 0.326 & 0.364 & 0.141 & 0.250 & 0.391 \\
$1980-1990$ & -0.037 & -0.041 & -0.078 & -0.032 & -0.034 & -0.066 & -0.559 & -0.558 & -1.117 \\
$1990-2000$ & 0.069 & -0.012 & 0.057 & -0.003 & -0.162 & -0.165 & -0.291 & -0.317 & -0.608 \\
$2000-2010$ & -0.039 & -0.086 & -0.125 & 0.021 & -0.099 & -0.078 & -0.038 & -0.013 & -0.052 \\
$2010-2015$ & -0.063 & -0.027 & -0.090 & -0.022 & 0.026 & 0.005 & 0.024 & 0.005 & 0.028 \\
$1980-2015$ & -0.070 & -0.166 & -0.236 & -0.036 & -0.269 & -0.305 & -0.864 & -0.884 & -1.748 \\
\hline
\end{tabular}

For the UAP, the total Theil index showed a downward trend, decreasing from 0.953 in 1980 to 0.717 in 2015 . However, only the inequality within megaregions showed an obvious trend for every interval, which decreased by 0.166 , from 0.494 to 0.327 . The decrease in $T_{a}$ was 0.070 , from 0.459 to 0.389. The downward trend of inequality was mainly caused by the downward trend of inequality within megaregions. The inequality among megaregions remained steady.

For the urban population density, the total Theil index showed a downward trend, except in 2010-2015. The total decrease was 0.305 , from 0.668 to 0.364 . The inequality within and among megaregions both showed downward trends. The total decreases in inequality within and among megaregions were 0.036 and 0.269 , respectively. These values reflected that the downward trend of the Theil index of that urban population density was mainly influenced by inequality within megaregions.

For the urban economic density, similar to the UAP, the total Theil index showed a downward trend, with a total decline of 1.748 from 1980 to 2015 . However, the downward trend of the inequality within and among megaregions contributed equally to the total downward trend of the inequality, with values of 0.864 and 0.884 , respectively.

The Theil index of each megaregion was calculated to measure the inequality of urban land and its efficiency within megaregions (Figure 6). The overall trend of the Theil index of the UAP was downward. The mean value decreased from 0.39 in 1980 to 0.35 in 2015, with a decrease of 0.002 per year. This result indicated that the regional divergence showed a slight downward trend in the UAP. YGA had a relatively high Theil index for the UAP in 1980, and then it showed a decreasing trend, decreasing from 0.74 in 1980 to 0.38 in 2015, with a decrease of 0.009 per year. A slight increase in the Theil index of the UAP was observed in CY, with 0.003 per year, which increased from 0.36 in 1980 to 0.58 in 2010 and then decreased to 0.53 in 2015.

The Theil index trend of the urban population density showed a more obvious downward trend. The mean value decreased from 0.63 in 1980 to 0.33 in 2015, with a decrease of 0.006 per year. Most megaregions showed different extents of decline except for CY. The most obvious decline occurred in YGA, which decreased from 0.99 in 1980 to 0.26 in 2015, with a 0.018 decrease per year. YRD and MYR exhibited similar trends. However, their rates of decrease were slower than that of YGA, with decreases of 0.009 and 0.010 per year, respectively.

The Theil index of urban economic density showed a steady trend. The change in the mean value of the Theil index of urban economic density was only \pm 0.001 per year, except in YGA. YGA showed a unique dynamic compared with other megaregions and had an obvious downward trend. The Theil index of urban economic density decreased obviously, from 1.56 in 1980 to 0.71 in 2015, with a 0.022 decrease per year. Even so, the Theil index in 2015 was far higher than that of other megaregions. JJJ, MYR, and YRD showed an upward trend, reflecting an increasing trend of urban land economic efficiency. 

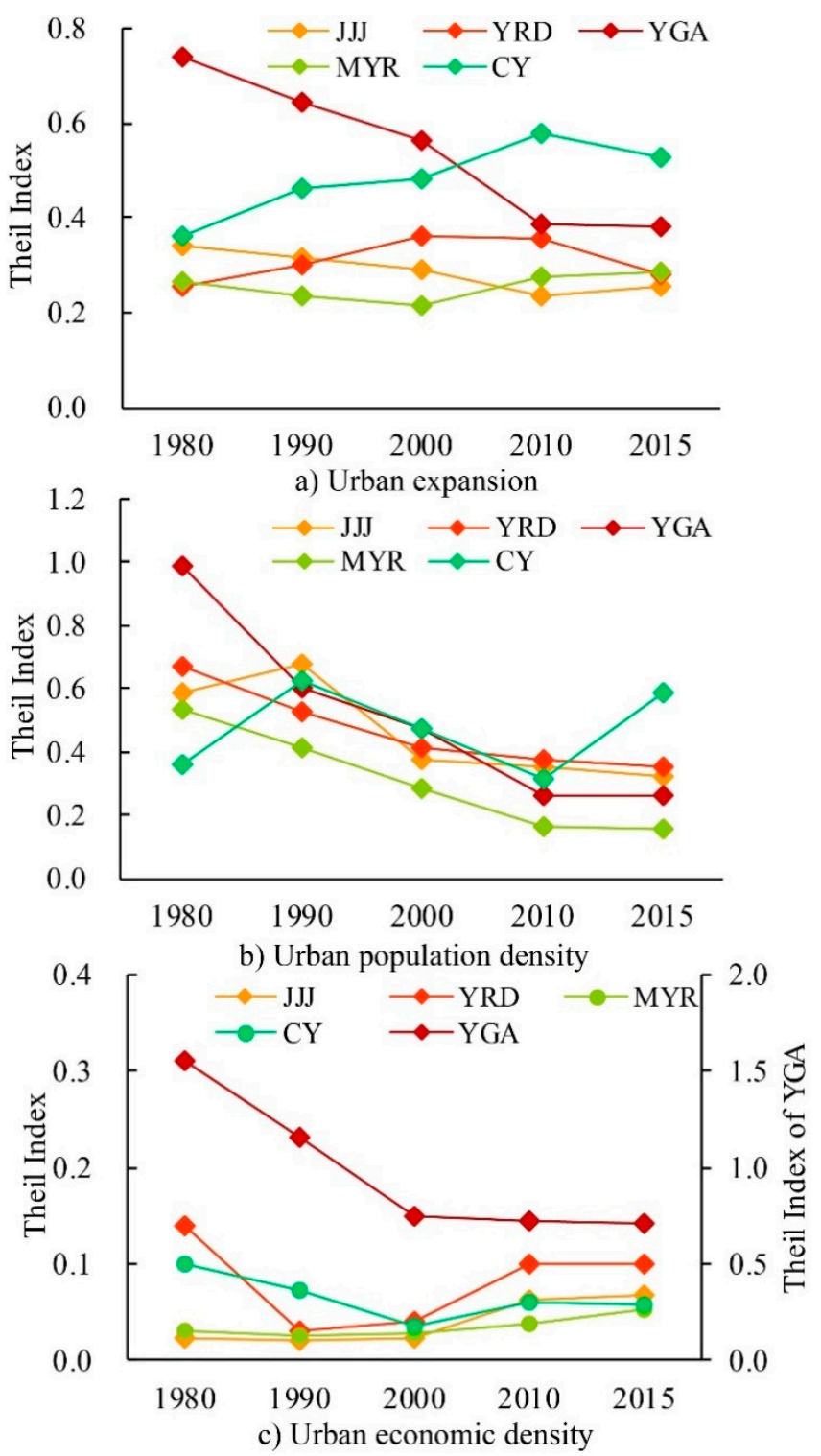

Figure 6. Changes in Theil index in different megaregions.

\section{Discussion}

\subsection{Regional Divergence of Degree of Artificial Construction Intensity}

Although five megaregions were planned at the national level, they saw regional divergence in the level of urbanization. The regional divergence was reflected by the urban land and efficiency indexes, which may be caused by many factors, such as policy, climate, demographics and terrain [23]. In addition, it can help for regional planning of the construction of megaregions. For the artificial construction intensity, CY had the highest DAP and the lowest proportion of urban land. The degree of artificial construction intensity was reflected by agriculture. As CY is located in Sichuan Basin, a major grain-producing area of China, it preserves more cropland than do other megaregions [61]. More UAP was observed in YGA, as a major urban cluster in China [47], and cities concentrate and cover most areas of the Pearl River estuary (Figure 1). As more woodland is distributed in this megaregion, they can be designed to undertake the function of urban green space through greening infrastructure, such as greenbelts [62]. 


\subsection{Differences of the Change of Efficiency Indexes}

The change of efficiency indexes showed different in urban population and economic density. This change is related to the development of China. China has experienced a rapid process of economic development since the policy of "reform and opening-up" in 1978 [23,38]. The speed of economic development is much faster than that of urban expansion. The change patterns of the urban population density and economic density had certain differences, which were mainly reflected by the speed of change. Relative to urban economic density, the growth rate of urban population density is slow. Although the urban population also experienced a rapid rise, the overall growth rate of major urban megaregions in China was basically in line with the pace of urban expansion. As a result of that, there was a slight increase in urban population density.

\subsection{Differently Developing Trajectories of Megaregions}

This study indicated that urban land efficiency experienced regional divergence among Chinese megaregions. The change of the indexes reflected a developmental trajectory of a megaregion. In addition, differences in various indexes during the same period can reflect divergence in regional development. An increasing trend in all megaregions indicated urban land expansion occurred after population migration. As the urban population grew, urban land expansion was constricted by new policy implementation [63]. The urban population distribution and GDP generated in these megaregions were relatively higher than those in JJJ, MYR and CY. As a result, they had a higher density than that of the other megaregions. Although JJJ is also an economic center of China, there was more GDP generated in megacities, such as Beijing and Tianjin. The economic density was relatively lower in other cities. This gap within megaregions pulls down the overall level in this megaregion [64]. Although MYR showed an increasing trend in the urban population and economic density, due to later development, the density was lower than that of the former developing megaregions. CY saw a relatively high urban density with the influence of less urban land, with relatively less urban land distribution.

The results showed that different degrees of inequality appeared in the five megaregions. For example, YGA had a relatively high Theil index of UAP before 1990 and showed a downward trend. As the administrative areas of cities in YGA are relatively small, urban land tends to be brimming with administrative units as a result of expansion. Then, the ratio of urban areas of cities tends to be equal. The decreasing trend was shown in urban population density and urban economic density. The most obvious phenomenon appeared in YGA, which witnessed the most development since the 1980s [65]. YGA showed an obviously downward trend. However, its inequality was higher than that of the other four megaregions. This result may be influenced by Hong Kong and Macao, which have relatively little urban land but contribute greatly to the GDP. This inequality tended to smooth as Guangdong developed. However, the gaps remained.

\subsection{Driving Forces of Urbanization for Different Megaregions}

Former studies informed that the physical factors, such as topography, were the fundamental for urban growth in megaregions [66,67]. As cities prefer to expand in flat areas, topography differences for megaregions might lead to different pattern for urban expansion [68,69], which drive similar expansion pattern for megaregions. Most urban expansion of JJJ has been located in the North China Plain, including two expansion cores, Beijing and Tianjin. The delta area of Yangtze River beside Shanghai occupied most urban expansion in YRD, instead of the hilly area in Zhejiang. Topography influenced urban expansion more obviously in YGA. As more hills are located in this megaregion, cities sprawl mostly in the flat delta of the Pearl River near the sea. Hills not suitable for urban construction were left for greening space.

Furthermore, the policy implements also played an important role in urban expansion in high and low-income countries. The macro policies urged population and economic growth in megaregions, 
then led urban expansion to contain more population and economic activities [25]. For example, the highest rate of expansion occurred in 2000-2010, which is consistent with the fast-economic growth period after joining the WTO in 2001. A similar phenomenon was observed by other researchers [25,70]. The different acceleration trends of megaregions may be due to the degree of development and implementation of policy. The expansion speeds of JJJ, YRD and YGA showed an accelerating trend before 2010 and then slowed in 2010-2015. This pattern may be caused by the rapidly-expanded urban boundary by 2010 , so the urban boundary tended to be controlled afterwards. Only MYR showed acceleration in all periods. This result may be caused by the implementation of the Rise of Central China Plan in 2006 [48]. The national plan promoted regional urban expansion to a certain degree [71].

\subsection{Inequality Changes from the Theil Index}

The Theil index was employed to measure the inequality among megaregions. The Theil index showed a decreasing trend after 1980 . This result indicated a decreasing trend in the regional differences. The inequality among megaregions and within megaregions both decreased obviously. With rapid urbanization since the 1980s, China has experienced dramatic changes throughout its territory. The differences among and within megaregions decreased as a result of regional development.

The Theil index was a useful tool for inequality analysis among megaregions. More detailed information can be extracted from the Theil index composition [46]. The inequality among megaregions decreased, according to our analysis. The degree of decrease of different indicators in different regions reflected the temporal change in the internal structure. During analysis, the Theil index used only a single index to measure regional inequality. The analysis results depend on the choice of index. In addition, the Theil index decomposition relies on the zoning method used to define regions. Different zoning methods (such as urban and rural areas, different regions) and data selection scales (such as prefecture level, county level) have an impact on the analysis results [44].

\section{Conclusions}

Based on the comparation of urban land and efficiency among megaregions with the CLUD and CLUD-Urban datasets, we depicted the development trajectories of five major megaregions in China. The following conclusions are emphasized: (1) Different megaregions experienced different degrees of artificial construction intensity, which was reflected by the percentage of urban land and developed land. The Guangdong-Hong Kong-Macao Great Bay Area had the highest proportion of urban land (64.70\%), while Chengdu-Chongqing had the highest proportion of developed land $(8.03 \%)$; (2) The five megaregions experienced rapid urban expansion, and the expansion accelerated before 2010 and then slowed in most megaregions. The highest urban expansion occurred in the Yangtze River Delta Megaregion in 1980-2015. The proportion of urban impervious surface area remained around approximately $70 \%$ in major megaregions; (3) China experienced a decreasing trend of inequality of urban land efficiency within and among megaregions, according to our study. The decreasing Theil index values of urban population and economic density were 0.305 and 1.748 , respectively, in 1980-2015.

This comparison helps to characterize metrics of megaregions from a larger perspective. Due to the difference in the degree of artificial construction intensity, we claim that differences in policy making and implementation are required for megaregion development. What causes the differences of urban land and their efficiency of different megaregions? It requires more local knowledge of a given megaregion to answer this question, which is important for the implementation of the National New-Type Urbanization Plan in China, and the local plan for each megaregion.

Author Contributions: Conceptualization, C.F., W.K.; methodology, S.Z., W.K.; writing-original draft preparation, S.Z.; writing—review and editing, S.Z., W.K., F.S.; project administration, C.F.; funding acquisition, C.F.

Funding: This research was funded by Major Program of the National Natural Science Foundation of China, grant number 41590842. 
Acknowledgments: Many thanks to anonymous reviewers for providing valuable opinion on revising the manuscript. We would also like to thank Yinyin Dou for the helpful comments on the manuscript.

Conflicts of Interest: The authors declare no conflict of interest.

\section{References}

1. Carlson, T.N.; Arthur, S.T. The impact of land use-Land cover changes due to urbanization on surface microclimate and hydrology: A satellite perspective. Glob. Planet Chang. 2000, 25, 49-65. [CrossRef]

2. Kuang, W.H.; Yang, T.R.; Liu, A.L.; Zhang, C.; Lu, D.S.; Chi, W.F. An EcoCity model for regulating urban land cover structure and thermal environment: Taking Beijing as an example. Sci. China Earth Sci. 2017, 60, 1098-1109. [CrossRef]

3. Grimm, N.B.; Grove, J.M.; Pickett, S.T.A.; Redman, C.L. Integrated approaches to long-term studies of urban ecological systems. Bioscience 2000, 50, 571-584. [CrossRef]

4. Bai, X.M.; Dawson, R.J.; Urge-Vorsatz, D.; Delgado, G.C.; Salisu Barau, A.; Dhakal, S.; Dodman, D.; Leonardsen, L.; Masson-Delmotte, V.; Roberts, D.C.; et al. Six research priorities for cities and climate change. Nature 2018, 555, 23-25. [CrossRef] [PubMed]

5. Shao, Q.Q.; Sun, C.Y.; Liu, J.Y.; He, J.F.; Kuang, W.H.; Tao, F.L. Impact of urban expansion on meteorological observation data and overestimation to regional air temperature in China. J. Geogr. Sci. 2011, 21, 994-1006. [CrossRef]

6. Kuang, W.H.; Dou, Y.Y.; Zhang, C.; Chi, W.F.; Liu, A.L.; Liu, Y.; Zhang, R.H.; Liu, J.Y. Quantifying the heat flux regulation of metropolitan land use/land cover components by coupling remote sensing modeling with in situ measurement. J. Geophys. Res.-Atmos. 2015, 120, 113-130. [CrossRef]

7. Yin, C.; Yuan, M.; Lu, Y.; Huang, Y.; Liu, Y. Effects of urban form on the urban heat island effect based on spatial regression model. Sci. Total Environ. 2018, 634, 696-704. [CrossRef] [PubMed]

8. Shen, H.Z.; Tao, S.; Chen, Y.L.; Ciais, P.; Guneralp, B.; Ru, M.Y.; Zhong, Q.R.; Yun, X.; Zhu, X.; Huang, T.B.; et al. Urbanization-induced population migration has reduced ambient PM2.5 concentrations in China. Sci. Adv. 2017, 3. [CrossRef] [PubMed]

9. Zhang, Z.X.; Wang, X.; Zhao, X.L.; Liu, B.; Yi, L.; Zuo, L.J.; Wen, Q.K.; Liu, F.; Xu, J.Y.; Hu, S.G. A 2010 update of National Land Use/Cover Database of China at 1:100000 scale using medium spatial resolution satellite images. Remote Sens. Environ. 2014, 149, 142-154. [CrossRef]

10. Che, X.Z.; Shang, J.C. Strategic environmental assessment for sustainable development in urbanization process in China. Chin. Geogr. Sci. 2004, 14, 148-152. [CrossRef]

11. He, C.Y.; Liu, Z.F.; Tian, J.; Ma, Q. Urban expansion dynamics and natural habitat loss in China: A multiscale landscape perspective. Glob. Chang. Biol. 2014, 20, 2886-2902. [CrossRef] [PubMed]

12. Peng, J.; Shen, H.; Wu, W.H.; Liu, Y.X.; Wang, Y.L. Net primary productivity (NPP) dynamics and associated urbanization driving forces in metropolitan areas: A case study in Beijing City, China. Landsc. Ecol. 2016, 31, 1077-1092. [CrossRef]

13. Seto, K.C.; Guneralp, B.; Hutyra, L.R. Global forecasts of urban expansion to 2030 and direct impacts on biodiversity and carbon pools. Proc. Natl. Acad. Sci. USA 2012, 109, 16083-16088. [CrossRef] [PubMed]

14. Zhou, W.Q.; Zhang, S.; Yu, W.J.; Wang, J.; Wang, W.M. Effects of urban expansion on forest loss and fragmentation in six megaregions, China. Remote Sens. 2017, 9, 991. [CrossRef]

15. Torre, C.; Morano, P.; Tajani, F. Saving soil for sustainable land use. Sustainability 2017, 9, 350. [CrossRef]

16. Liu, F.; Zhang, Z.X.; Zhao, X.L.; Wang, X.; Zuo, L.J.; Wen, Q.K.; Yi, L.; Xu, J.Y.; Hu, S.G.; Liu, B. Chinese cropland losses due to urban expansion in the past four decades. Sci. Total Environ. 2019, 650, 847-857. [CrossRef]

17. Shi, K.F.; Chen, Y.; Yu, B.L.; Xu, T.B.; Li, L.Y.; Huang, C.; Liu, R.; Chen, Z.Q.; Wu, J.P. Urban expansion and agricultural land loss in China: A multiscale perspective. Sustainability 2016, 8, 790. [CrossRef]

18. Tan, M.H.; Li, X.B.; Xie, H.; Lu, C.H. Urban land expansion and arable land loss in China-A case study of Beijing-Tianjin-Hebei region. Land Use Policy 2005, 22, 187-196. [CrossRef]

19. United Nations, Department of Economic and Social Affairs, Population Division. World Urbanization Prospects: The 2018 Revision; United Nations: San Francisco, CA, USA, 2018. 
20. Schneider, A.; Mertes, C.M.; Tatem, A.J.; Tan, B.; Sulla-Menashe, D.; Graves, S.J.; Patel, N.N.; Horton, J.A.; Gaughan, A.E.; Rollo, J.T.; et al. A new urban landscape in East-Southeast Asia, 2000-2010. Environ. Res. Lett. 2015, 10, 034002. [CrossRef]

21. Rimal, B.; Zhang, L.F.; Stork, N.; Sloan, S.; Rijal, S. Urban expansion occurred at the expense of agricultural lands in the Tarai region of Nepal from 1989 to 2016. Sustainability 2018, 10, 1341. [CrossRef]

22. Liu, X.P.; Hu, G.H.; Chen, Y.M.; Li, X.; Xu, X.C.; Li, S.Y.; Pei, F.S.; Wang, S.J. High-resolution multi-temporal mapping of global urban land using Landsat images based on the Google Earth Engine Platform. Remote Sens. Environ. 2018, 209, 227-239. [CrossRef]

23. Bai, X.M.; Shi, P.J.; Liu, Y.S. Society: Realizing China's urban dream. Nature 2014, 509, 158-160. [CrossRef] [PubMed]

24. Schneider, A.; Mertes, C.M. Expansion and growth in Chinese cities, 1978-2010. Environ. Res. Lett. 2014, 9, 24008. [CrossRef]

25. Kuang, W.H.; Liu, J.Y.; Dong, J.W.; Chi, W.F.; Zhang, C. The rapid and massive urban and industrial land expansions in China between 1990 and 2010: A CLUD-based analysis of their trajectories, patterns, and drivers. Landsc. Urban Plan. 2016, 145, 21-33. [CrossRef]

26. Bhatta, B.; Saraswati, S.; Bandyopadhyay, D. Urban sprawl measurement from remote sensing data. Appl. Geogr. 2010, 30, 731-740. [CrossRef]

27. Gao, B.; Huang, Q.X.; He, C.Y.; Sun, Z.X.; Zhang, D. How does sprawl differ across cities in China? A multi-scale investigation using nighttime light and census data. Landsc. Urban Plan. 2016, 148, 89-98. [CrossRef]

28. Pan, T.; Lu, D.S.; Zhang, C.; Chen, X.; Shao, H.; Kuang, W.H.; Chi, W.F.; Liu, Z.J.; Du, G.M.; Cao, L.Z. Urban land-cover dynamics in arid China based on high-resolution urban land mapping products. Remote Sens. 2017, 9, 730. [CrossRef]

29. Seto, K.C.; Fragkias, M. Quantifying spatiotemporal patterns of urban land-use change in four cities of China with time series landscape metrics. Landsc. Ecol. 2005, 20, 871-888. [CrossRef]

30. Liu, Z.F.; He, C.Y.; Wu, J.G. General spatiotemporal patterns of urbanization: An examination of 16 world cities. Sustainability 2016, 8, 1-15. [CrossRef]

31. Jiao, L.M. Urban land density function: A new method to characterize urban expansion. Landsc. Urban Plan. 2015, 139, 26-39. [CrossRef]

32. Lu, D.S.; Weng, Q.H. Use of impervious surface in urban land-use classification. Remote Sens. Environ. 2006, 102, 146-160. [CrossRef]

33. Wu, C.S.; Murray, A.T. Estimating impervious surface distribution by spectral mixture analysis. Remote Sens. Environ. 2003, 84, 493-505. [CrossRef]

34. Kuang, W.H. Mapping global impervious surface area and green space within urban environments. Sci. China Earth Sci. 2019. [CrossRef]

35. Hasse, J.E.; Lathrop, R.G. Land resource impact indicators of urban sprawl. Appl. Geogr. 2003, 23, $159-175$. [CrossRef]

36. Liu, H.M. Comprehensive carrying capacity of the urban agglomeration in the Yangtze River Delta, China. Habitat Int. 2012, 36, 462-470. [CrossRef]

37. Zhou, W.Q.; Jiao, M.; Yu, W.J.; Wang, J. Urban sprawl in a megaregion: A multiple spatial and temporal perspective. Ecol. Indic. 2019, 96, 54-66. [CrossRef]

38. Kuang, W.H.; Liu, J.Y.; Zhang, Z.X.; Lu, D.S.; Xiang, B. Spatiotemporal dynamics of impervious surface areas across China during the early 21st century. Chin. Sci. Bull. 2013, 58, 1691-1701. [CrossRef]

39. Zhang, C.; Chen, Y.L.; Lu, D.S. Mapping the land-cover distribution in arid and semiarid urban landscapes with Landsat Thematic Mapper imagery. Int. J. Remote Sens. 2015, 36, 4483-4500. [CrossRef]

40. Jiang, F.; Liu, S.H.; Yuan, H.; Zhang, Q. Measuring urban sprawl in Beijing with geo-spatial indices. J. Geogr. Sci. 2007, 17, 469-478. [CrossRef]

41. Dablanc, L.; Ross, C. Atlanta: A mega logistics center in the Piedmont Atlantic Megaregion (PAM). J. Transp. Geogr. 2012, 24, 432-442. [CrossRef]

42. Fang, C.L. Important progress and future direction of studies on China's urban agglomerations. J. Geogr. Sci. 2015, 25, 1003-1024. [CrossRef]

43. Marull, J.; Galletto, V.; Domene, E.; Trullen, J. Emerging megaregions: A new spatial scale to explore urban sustainability. Land Use Policy 2013, 34, 353-366. [CrossRef] 
44. Wei, Y.H.D.; Li, H.; Yue, W.Z. Urban land expansion and regional inequality in transitional China. Landsc. Urban Plan. 2017, 163, 17-31. [CrossRef]

45. Yu, W.J.; Zhou, W.Q. The spatiotemporal pattern of urban expansion in China: A comparison study of three urban megaregions. Remote Sens. 2017, 9, 45. [CrossRef]

46. Yu, W.J.; Zhou, W.Q. Spatial pattern of urban change in two Chinese megaregions: Contrasting responses to national policy and economic mode. Sci. Total Environ. 2018, 634, 1362-1371. [CrossRef] [PubMed]

47. Tan, M.H. Uneven growth of urban clusters in megaregions and its policy implications for new urbanization in China. Land Use Policy 2017, 66, 72-79. [CrossRef]

48. Chen, M.X.; Liu, W.D.; Lu, D.D. Challenges and the way forward in China's new-type urbanization. Land Use Policy 2016, 55, 334-339. [CrossRef]

49. Su, S.L.; Liu, Z.B.; Xu, Y.F.; Li, J.; Pi, J.H.; Weng, M. China's megaregion policy: Performance evaluation framework, empirical findings and implications for spatial polycentric governance. Land Use Policy 2017, 63, 1-19. [CrossRef]

50. Wu, J.G. Urban ecology and sustainability: The state-of-the-science and future directions. Landsc. Urban Plan. 2014, 125, 209-221. [CrossRef]

51. Wu, J.G.; Xiang, W.N.; Zhao, J.Z. Urban ecology in China: Historical developments and future directions. Landsc. Urban Plan. 2014, 125, 222-233. [CrossRef]

52. Fang, C.L.; Wang, Z.B.; Ma, H.T. The theoretical cognition of the development law of China's urban agglomeration and academic contribution. Acta Geogr. Sin. 2018, 651-665. (In Chinese) [CrossRef]

53. Ning, J.; Liu, J.Y.; Kuang, W.H.; Xu, X.L.; Zhang, S.W.; Yan, C.Z.; Li, R.D.; Wu, S.X.; Hu, Y.F.; Du, G.M.; et al. Spatiotemporal patterns and characteristics of land-use change in China during 2010-2015. J. Geogr. Sci. 2018, 28, 547-562. [CrossRef]

54. Liu, J.Y.; Kuang, W.H.; Zhang, Z.X.; Xu, X.L.; Qin, Y.W.; Ning, J.; Zhou, W.C.; Zhang, S.W.; Li, R.D.; Yan, C.Z.; et al. Spatiotemporal characteristics, patterns, and causes of land-use changes in China since the late 1980s. J. Geogr. Sci. 2014, 24, 195-210. [CrossRef]

55. Yang, Q.K.; Duan, X.J.; Wang, L.; Jin, Z.F. Land Use Transformation Based on Ecological-production-living Spaces and Associated Eco-environment Effects: A Case Study in the Yangtze River Delta. Sci Geogr. Sin. 2017, 38, 97-106. (In Chinese) [CrossRef]

56. Ridd, M.K. Exploring a V-I-S (vegetation-impervious surface-soil) model for urban ecosystem analysis through remote sensing: Comparative anatomy for cities. Int. J. Remote Sens. 1995, 16, 2165-2185. [CrossRef]

57. Kuang, W.H.; Zhang, S.; Li, X.Y.; Lu, D.S. A national urban land use/cover change dataset (CLUD-Urban) in China, 2000-2015. Zenodo 2019. [CrossRef]

58. National Bureau of Statistics. China Statistical Yearbook (1981, 1991, 2001, 2011 and 2016); China Statistics Press: Beijing, China, 2017. (In Chinese)

59. National Bureau of Statistics. China City Statistical Yearbook (1991, 2001, 2011 and 2016); China Statistics Press: Beijing, China, 2017. (In Chinese)

60. Theil, H. Economics and Information Theory; Rand McNally and Company: Chicago, IL, USA, 1967.

61. Fan, M.; Chen, L. Spatial characteristics of land uses and ecological compensations based on payment for ecosystem services model from 2000 to 2015 in Sichuan Province, China. Ecol. Inform. 2019, 50, 162-183. [CrossRef]

62. Hong, W.Y.; Guo, R.Z. Indicators for quantitative evaluation of the social services function of urban greenbelt systems: A case study of shenzhen, China. Ecol. Indic. 2017, 75, 259-267. [CrossRef]

63. Wei, Y.H.D.; Ye, X. Beyond Convergence: Space, Scale, And Regional Inequality In China. Tijdschr. Voor Econ. Soc. Geogr. 2009, 100, 59-80. [CrossRef]

64. Lu, D.D. Function orientation and coordinating development of subregions within the Jing-Jin-Ji Urban Agglomeration. Prog. Geogr. 2015, 34, 265-270. (In Chinese)

65. Zhang, L.; Weng, Q.H. Annual dynamics of impervious surface in the Pearl River Delta, China, from 1988 to 2013, using time series Landsat imagery. ISPRS J. Photogramm. 2016, 113, 86-96. [CrossRef]

66. Li, X.M.; Zhou, W.; Ouyang, Z. Forty years of urban expansion in Beijing: What is the relative importance of physical, socioeconomic, and neighborhood factors? Appl. Geogr. 2013, 38, 1-10. [CrossRef]

67. Aspinall, R. Modelling land use change with generalized linear models-A multi-model analysis of change between 1860 and 2000 in Gallatin Valley, Montana. J. Environ. Manag. 2004, 72, 91-103. [CrossRef] [PubMed] 
68. Müller, K.; Steinmeier, C.; Küchler, M. Urban growth along motorways in Switzerland. Landsc. Urban Plan. 2010, 98, 3-12. [CrossRef]

69. Zhang, Z.X.; Li, N.; Wang, X.; Liu, F.; Yang, L.P. A comparative study of urban expansion in Beijing, Tianjin and Tangshan from the 1970s to 2013. Remote Sens. 2016, 8, 496. [CrossRef]

70. Wang, S.J.; Ma, H.T.; Zhao, Y.B. Exploring the relationship between urbanization and the eco-environment-A case study of Beijing-Tianjin-Hebei region. Ecol. Indic. 2014, 45, 171-183. [CrossRef]

71. Kim, S. Spatial Inequality and Economic Development; World Bank: Washington, DC, USA, 2008.

(C) 2019 by the authors. Licensee MDPI, Basel, Switzerland. This article is an open access article distributed under the terms and conditions of the Creative Commons Attribution (CC BY) license (http://creativecommons.org/licenses/by/4.0/). 